\title{
CULTURAL INSTITUTES - ENABLERS OF SUSTAINABLE DEVELOPMENT
}

\author{
Constantin, OPREAN ${ }^{1}$, Eva Nicoleta, BURDUSEL ${ }^{2}$, Liu, QIAN $^{3}$ \\ "Lucian Blaga" University of Sibiu, Romania, e-mail constantin.oprean@ulbsibiu.ro \\ "Lucian Blaga" University of Sibiu, Romania, e-mail eva.burdusel@ulbsibiu.ro \\ Beijing Language and Culture University, Confucius Institute, China e-mail qianliu2011@gmail.com
}

\begin{abstract}
The primary goal of this study is to examine the role of culture - as one of the most enduring, vital and long-lived components of sustainable development, with multifarious potential continuously explored and capitalized by individuals, communities or institutions. All definitions of the phrase sustainable development include culture as a sine-qua-non element that is also inextricably connected and interdependent with the other three pillars: economic, social and environmental. In this context of cultural centres worldwide, Confucius Institutes represent a successful and efficient managerial model by capitalizing on the most important resource of an organization: human capital.
\end{abstract}

KEY WORDS: sustainable development, culture, human capital, resource, intangible asset

\section{A CULTURAL APPROACH TO SUSTAINABLE DEVELOPMENT}

The primary goal of this study is to examine the role of culture - as one of the most enduring, vital and long-lived components of sustainable development, with multifarious potential continuously explored and capitalized by individuals, communities or institutions.

All definitions of the phrase sustainable development include culture as a sine-qua-non element that is also inextricably connected and interdependent with the other three pillars: economic, social and environmental. [1]

The regenerative and abiding power of culture as well as its ability to provide continuity in tradition, preserve heritage, promote tangible or intangible cultural asset are highlighted in a great number of UNESCO documents. "Culture helps to reestablish ties broken by conflict ... It determines a people`s ability to project their designs into the future and develop. It also enables them to recover when disaster strikes and overcome obstacles." [2] Furthermore, "in today's interconnected world, culture's power to transform societies is clear. Its diverse manifestations - from our cherished historic monuments, and museums to traditional practices and contemporary art forms - enrich our everyday lives in countless ways." [3]

The core idea of "culture as driver and enabler of sustainable development" has been minutely and thoroughly outlined in a 2012 thematic think piece drafted by the UN System Task Team on the Post-2015 UN Development Agenda as follows: "Throughout the past decade, statistics, indicators and data on the cultural sector as well as operational activities have underscored that culture can be a powerful driver for development, within communitywide, social, economic and environmental impacts. Cultural and creative industries represent one of the most rapidly expanding sectors in the global economy." [4] "Acknowledging and promoting respect for cultural diversity within a human right based approach, moreover, can facilitate intercultural dialogue, prevent conflicts and protect the rights of marginalized groups, within and between nations, thus creating optimal conditions for achieving development goals. Culture, understood this way, makes development more sustainable." [5] Based on the aforementioned arguments, it is thus imperative to include culture in the policies and strategies for national development of international cooperation for economic growth and social cohesion, endorsed by a set of normative and legislative documents.

In this respect, in the framework of UCLG - The Global Network of Cities, Local and Regional Governments - the document Culture 21. Actions sets forth a number of 'commitments' structures into nine sections: cultural rights; heritage, diversity and creativity; culture and education; culture and environment; culture and economy; culture, equality and social inclusion; culture urban planning and public space; culture, information and knowledge; governance of culture thus summarizing the cultural dimension of sustainability as well as strengthening the connection between culture and education. [6]

The Convention on the Protection and Promotion of the Diversity of Cultural Expression is an essential document for understanding the contemporary global context, whose mission and aim are to highlight cultural diversity as a fundamental human and cultural right, in view of cooperation for mutual benefit. Special attention is given to linguistic diversity as a "fundamental element of cultural diversity" as well as the role played by education "in the protection and promotion of cultural expression." [7] Some of its main objectives are: "to 31 
encourage dialogue among cultures with a view to ensuring wider and balanced cultural exchanges in the world in favour of intercultural respect and a culture of peace; to foster interculturality in order to develop cultural interaction in the spirit of building bridges among peoples; to promote respect for the diversity of cultural expressions and raise awareness of its value at the local, national and international levels." [8]

\section{CASE STUDY}

Cultural institutes are one of the most relevant examples in the attempt to promote and connect cultures, which have been set up on a similar, though not identical pattern, in view of creating a stronger sense of self-identity and contributing to an integration of diversity by mutually accepted knowledge and dialogue. [9] As Judith Eva Furjesz summed up in her study on The Role of Cultural Institutes in the European Integration, they have a threefold purpose and the respective means, methods and organization to attain them successfully: a) for the "diffusion of national language ... cultural institutes are in the same time language schools for students, formation schools for language teachers and certificate centres for the release of language exams"; b) representing and promoting "national culture, cultural heritage, society, customs ... by the organization of cultural events or by the lobbying of national artists"; c) since "culture is also knowledge, science ... these institutes ... help the studies abroad, to become attractive for smart-brains to bring them in their country to contribute to the national science, with scholarships." [10]

As most scholars have rightly noted, the scope of cultural institutes - British Council, Alliance Francaise, Goethe Institut, Institute Cervantes, Romanian Cultural Institutes, Confucius Institute - is more comprehensive than merely the promotion of one's language, culture and civilization; instead it focuses on dialogue and cooperation, endorsed by the ability to accommodate multiple voices, which highlights the essential role of the humanities, wisely argumented by Martha Nussbaum, in her essay "Skills for Life":

... by searching critical thought, daring imagination, empathetic understanding of human experiences of many different kinds, and understanding of the complexity of the world we live in - a world in which people face one another across gulfs of geography, language and nationality. More than at any time in the past, we all depend on people we have never seen, and they depend on us ... The global economy has tied all of us to distant lives ... The ability to think well about a wide range of cultures, groups, and nations and the history of their interactions is crucial in enabling democracies to deal responsibly with the problems we currently face ... Citizens cannot relate well to the complex world around them by factual knowledge and logic alone. The third ability of the citizen, closely related to those two, is what we can call the narrative imagination. This means the ability to think what it might be like to be in the shoes of a person different from oneself, to be an intelligent reader of that person's story, to understand the emotions and wishes and desires that someone so placed might have. [11]

Within the wider international context that has contributed to spreading cultural institutes abroad, special mention should be made here of Confucius Institutes which share the purpose of similar institutions, however they are in a class by themselves, since their major difference and cutting-edge advantage lies in their organization, i.e. CIs are set up worldwide as a result of the partnership between two universities - a Chinese HEI and a corresponding one in the host country. Such an innovative approach has proved to be not only successful but also keeping up with the times, as it acknowledges and makes the best of the most important asset of any organization, i.e. human resource. Universities attract and retain the critical mass of experts in the field of cultural promotion and interaction, teaching methods since academic endeavours, in both teaching and research, are equally retrospective, able to provide an insight not only into tradition and heritage, as well as anticipative and prospective, defining the contemporary context and envisioning future trends.

This explains the statement that "cultural diplomacy is a matter of attitude and education" [12] whereas Martha Nussbaum pleads for "cultivating humanity" as the "arts play a vital role, cultivating the power of imagination, essential to citizenship." [13]

Jose Ortega y Gasset outlined the "mission of the university", in his seminal homonymous essay, reflecting the close connection between education and culture: "culture should lie at the heart of universities" as culture embodies the vital system of ideas, traditions, customs of any age; hence the creation and dissemination of culture represents the third major dimension and pillar of university mission, in addition to teaching and research. [14]

In this context, we consider that Confucius Institutes fully meet all three dimensions of an academic institution, besides enjoying worldwide acceptance and success as a cultural centre, and establishing economic networks for mutual benefit. We may refer to this unique managerial pattern as vertical evolution with a thorough and in-depth focus on educational development - teaching Chinese language and culture; cultural promotion - organizing a plethora of cultural events, and research activities - organizing international conferences and symposia, inviting prestigious guest speakers, translation projects. As regards the principles for running a Confucius Institute, a harmonious managerial model has been adopted, i.e. the president of the host university is also president of the CI Board thus ensuring a coherent administration and integration within the local HEI further supported by two Directors: Chinese and local, to facilitate synergy of decisions, reciprocal consultation and intercultural communication based on competent decision-making process and cultural awareness.

\section{CONCLUSIONS}

To conclude, Confucius Institutes are equally independent units, financed and governed by / under the authority of Hanban, which can only operate properly and successfully when integrated within the entire institutional framework if a higher education institution; Thus, universities evince two of their most innovative and creative functions: receptiveness and responsiveness to society, its challenges and demands alike, in addition to being responsible by reflecting and guiding the policymaking process.

In this respect, the concept of total quality management in higher education is a useful tool in attaining excellence and achieving its mission, vision and goals, clearly set forth in its operational development plan. The most important sources in higher education to be capitalized for quality assurance are:

- $\quad$ outstanding academic staff

- $\quad$ high moral values

- excellent examination results

- the support of business and local community

- plentiful resources

- the application of the latest technology 
- $\quad$ strong and purposeful leadership

- the care and concern for students

- a well-balanced and challenging curriculum [15]

\section{References:}

1. for further reference see UNESCO website at http://en.unesco.org/themes/culture-sustainabledevelopment and Culture the Fourth Pillar of Sustainable Development http://www.agenda21culture.net/index.php/docman/1/393-zzculture4pillarsden/file

2. http://unesdoc.unesco.org/images/0018/001896/189621e.p $\underline{\mathrm{df}}$

3. $\underline{\mathrm{http}}$ ://en.unesco.org/themes/protecting-our-heritage-andfostering-creativity

4. http://en.unesco.org/post2015/sites/post2015/files/Think\% 20Piece\%20Culture.pdf pp.3-4

5. idem p. 5

6. http://www.agenda21culture.net/images/a21c/nuevaA21C/C21A/C21 015 en.pdf

7. UNESCO Convention on the Protection and Promotion of the Diversity of Cultural Expression, Paris, 20 Oct. 2005, pp. 2-3
8. Idem $\mathrm{p} 4$

9. Judith Eva Furjesz, The Role of Cultural Institutes in the European Integration 2013“... national cultural institutes abroad contribute to re-establish the peaceful international relations, since through the opening toward other cultures, the differences can be known, understood, and it leads finally to the respect of each other." P. 4, text available online at www.culturaldiplomacy.org

10. Idem pp. 6-7

11. Martha Nussbaum "Skills for Life" in Times Literary Supplement, $6^{\text {th }}$ April 2010, pp.2,4

12. Dr. Fabrice Serodes, A Common European Cultural Diplomacy in ICD Case Studies, p. 9 available at www.culturaldiplomacy.org

13. Martha Nussbaum, Cultivating Humanity, Harvard College, 1997, p.85

14. Gasset, Jose Ortega y, "Misiunea Universitatii”, Bucuresti: Ed. Univers, 1999

15. Sallis, Edward, Total Quality Management in Education, 3rd edition, London: 2002, pp.1-2; 3-4 